\title{
KETERAMPILAN PENGAMBILAN KEPUTUSAN DAN HASIL BELAJAR KIMIA SISWA DI SMA/MA NEGERI MATARAM DITINJAU DARI PENERAPAN METODE PEMBELAJARAN
}

\section{DECISION-MAKING SKILL AND STUDENTS' CHEMISTRY LEARNING OUTCOMES IN SMA/MA NEGERI MATARAM BASED ON THE APPLICATION OF THE LEARNING METHOD}

\author{
I Gede Karunia Soenarko*, Yayuk Andayani, Eka Junaidi \\ ${ }^{2}$ Program Studi Pendidikan Kimia, Jurusan Pendidikan MIPA, Fakultas Keguruan dan Ilmu Pendidikan, \\ Universitas Mataram. Jalan Majapahit No 62 Mataram, 83125, Indonesia \\ *Email: gedesoenarko27@,gmail.com
}

Diterima: 2 Februari 2018. Disetujui: 9 September2018. Dipublikasikan: 25 September 2018

\begin{abstract}
Abstrak. Penelitian ini bertujuan untuk mengetahui hubungan antara metode pembelajaran dengan keterampilan pengambilan keputusan dan hasil belajar kimia siswa kelas XI IPA di SMA/MA Negeri Mataram. Penelitian deskritif Expost Facto ini menggunakan subjek penelitian siswa kelas XI IPA di MAN 1 Mataram, SMAN 2 Mataram, dan SMAN 6 Mataram yang terbagi dalam 14 kelas dengan jumlah sampel sebanyak 236 orang. Pengumpulan data keterampilan pengambilan keputusan siswa dengan angket dan observasi sebagai pendukung, sedangkan data hasil belajar kimia diperoleh dari dokumentasi guru mata pelajaran kimia. Uji coba instrumen dilakukan pada 30 responden. Uji validitas instrumen menggunakan korelasi Product Moment, dan uji reliabilitas menggunakan rumus Alpha Cronbach's. Hasil uji hipotesis menggunakan uji anakova satu jalur diperoleh $F_{\text {hitung }}>F_{\text {tabel }}(22,58>3,03)$ pada taraf signifikan $5 \%$ yang menunjukkan bahwa ada hubungan antara metode pembelajaran dengan keterampilan pengambilan keputusan dan hasil belajar kimia siswa kelas XI IPA di SMA/MA Negeri Mataram Tahun Ajaran 2017/2018.
\end{abstract}

KataKunci: Keterampilan pengambilan keputusan, metode pembelajaran, hasil belajar kimia.

\begin{abstract}
This research aims to determine the correlation between learning methods with decision-making skill and students' chemistry learning learning outcomes of XI Sainsclass in SMA/MA Negeri at Mataram. This Expost Facto descriptive research uses the subjects of XI Sains in MAN 1 Mataram, SMAN 2 Mataram, and SMAN 6 Mataram which is divided into 14 classes with 236 samples. Data collection of student decision making skill withquestionnaire and observationas secondary, while learning outcomes data obtained from daily test result on chemistry subject. An experimental test conducted on 30 respondents. Test instrument validity uses Product Moment correlation, and reliability test uses Alpha Cronbach's formula. Data analysis techniques used is simple correlation analysis techniques. Hypothesis tested by one way Ancova resulted in $F_{\text {score }}>F_{\text {tabel }}(22,58>3,03)$ at the significant level of 5\% which signify alternative hypothesis $\left(H_{0}\right)$ denied. Based on this, it can be concluded that there is a correlation between learning methods with decision making and student chemistry learning outcomes of class XI Sains in SMA/MA Negeri Mataram in academic year of 2017/2018.
\end{abstract}

Keywords: Decision-making skill, chemistry learning, learning outcomes.

\section{PENDAHULUAN}

Banyak peristiwa yang terjadi dalam kehidupan sehari-hari yang dihadapi terkait dengan ilmu pengetahuan alam (IPA), seperti: fisika, kimia, dan biologi. Jika seorang individumengasosiasikan peristiwa yang mereka alami dengan apa yang mereka pelajari di sekolah, maka akanmemberikan kontribusi banyak untuk literasi sains mereka. Asosiasi ini dapat dibentuk dengan cara individu atau siswa belajar tentang lingkungan mereka, belajar tentang peristiwa alam yang terjadi melalui konsep dasar, prinsip dan generalisasi. Dengan cara ini, siswa juga memperoleh kemampuan berpikir ilmiah dan keterampilan dalam memecahkan suatu masalah [1-3].

Salah satu keterampilan dalam memecahkan masalah adalah keterampilan pengambilan keputusan. Pentingnya keterampilan pengambilan keputusan itu juga sudah menjadi tujuan dari pembelajaran ilmu pengetahuan alam (IPA) mulai dari tingkat sekolah dasar (SD) hingga tingkat sekolah menengah atas (SMA), bahkan pada tingkat perguruan tinggi (PT). Salah satu tujuan pembelajaran IPA yang tertuang dalam Permendiknas Nomor 22 Tahun 2006 tentang Standar Isi adalah untuk mengembangkan keterampilan proses untuk menyelidiki alam sekitar, memecahkan masalah dan pengambilan keputusan. Keterampilan pengambilan keputusan itu melibatkan keterampilan dalam berpikir. Berpikir secara umum diartikan sebagai suatu proses dalam ranah kognitif, suatu aktivitas mental yang dengan sendirinya akan memperoleh pengetahuan [4-6].

Ilmu kimia merupakan cabang dari ilmu pengetahuan alam (IPA) yang mempelajari tentang sifat, struktur materi, komposisi materi, perubahan, dan energi yang menyertai perubahan [7]. Cara mempelajari ilmu kimia adalah dengan menggunakan cara atau metode yang digunakan para ilmuwan untuk memperoleh ilmu pengetahuan tersebut. Metode yang 
digunakan para ilmuwan adalah metode ilmiah, terdapat hubungan yang erat antara metode ilmiah dengan keterampilan pengambilan keputusan, terutama ketika sampai pada penggunaaan aturan yang logis dan berdasarkan atas kenyataan untuk mendifinisikan masalah, merumuskan dan menguji hipotesis, dan mewujudkan hasil ke dalam suatu tindakan $[8,9]$.

Pengambilan keputusan merupakan suatu proses dalam memutuskan tindakan apa saja yang akan diambil atau dilakukan, biasanya melibatkan suatu pilihan-pilihan. Oleh sebab itu, pengambilan keputusan dapat diartikan sebagai proses dalam berpikir dengan menggunakan penalaran untuk mengidentifikasi pilihan-pilihan yang baik dari pilihan-pilihan yang kurang baik sesuai kriteria yang telah ditetapkan sampai mengambil keputusan dan bertindak. Adapun langkah-langkah dalam pengambilan keputusan secara umum adalah merumuskan masalah, mengumpulkan informasi yang relevan, membangun pilihan-pilihan, mengevaluasi pilihan, dan mengambil keputusan [10].

Hasil observasi mata pelajaran kimia di tiga sekolah, yaitu: MAN 1 Mataram, SMAN 2 Mataram, dan SMAN 6 Mataram memiliki nilai rata-rata sekolah yang berbeda.Ada beberapa faktor yang dapat menyebabkan perbedaan nilai rata-rata tersebut, diantaranya: banyak siswa hanya mampu menghafal dengan baik terhadap suatu materi pelajaran yang diterimanya, tetapi nyatanya belum mampu untuk memahaminya. Sebagian besar siswa juga belum mampu menghubungkan antara apa yang mereka pelajari dengan bagaimana pengetahuan tersebut akan dipergunakan atau dimanfaatkan. Keterampilan pengambilan keputusan pada siswa belum dilatih dengan baik. Hal ini telah dikomfirmasi oleh guru mata pelajaran kimia di sekolah bahwa belum pernah untuk mecoba melihat dan menilai keterampilan pengambilan keputusan siswa.

Hal ini sesuai dengan hasil wawancara dengan guru mata pelajaran kimia di MAN 1 Mataram, SMAN 2 Mataram, dan SMAN 6 Mataram diperoleh informasi tentang pembelajaran kimia di MAN 1 Mataram, SMAN 2 Mataram, dan SMAN 6 Matarampembelajaran yang dilakukan masih menggunakan metode konvensional, misalnya: ceramah, diskusi, dan tanya jawab.Proses pembelajaran kimia dengan cara mencatat dan mendengarkan penjelasan guru saja, tanpa mencoba untuk mengkaitkan dengan permasalahan dalam kehidupan sehari-hari membuat siswa cenderungkurang memahami dengan baik materi yang telah disampaikan oleh guru. Guru beranggapan bahwa menggunakan atau menerapkan metode pembelajaran yang baru akan menemui kesulitan dalam penerapannya.

Berdasarkan latar belakang masalah yang telah dipaparkan di atas, maka dapat dirumuskan permasalahan yang diteliti pada penelitian ini adalah apakah ada hubungan antara metode pembelajaran dengan keterampilan pengambilan keputusandan hasil belajar kimia siswa kelas XI IPA di SMA/MANegeri MataramTahun Ajaran 2017/2018? Tujuan penelitian ini adalah untuk mengetahuiada atau tidak ada hubungan antara metode pembelajaran dengan keterampilan pengambilan keputusan dan hasil belajar kimia siswa kelas XI IPA SMA/MANegeri Mataram Tahun Ajaran 2017/2018.

\section{METODOLOGI PENELITIAN}

Penelitian ini dilaksanakan di tiga sekolah, yaitu: MAN 1 Mataram, SMAN 2 Mataram, dan SMAN 6 Mataram pada semester I (ganjil) Tahun Ajaran 2017/2018 selama satu bulan (Agustus 2018September 2018). Penelitian ini dibagi dalam 3 tahapan, yakni 1) tahap perencanaan, 2) tahap pelaksanaan penelitian, dan 3) tahap pengolahan data.

Penelitian ini merupakan penelitian kuantitatif dengan metode expost facto. Penelitian expost facto meneliti hubungan sebab-akibat yang tidak dimanipulasi atau diberi perlakuan oleh peneliti. Tujuan penelitian dengan menggunakan metode expost facto adalah untuk menyelidiki apakah kondisi yang sudah ada bisa jadi menyebabkan perbedaan dalam kelompok subjek, di mana variabel dalam penelitian ini adalah metode pembelajaran, keterampilan pengambilan keputusan, dan hasil belajar kimia siswa kelas XI IPA [11].

Populasi yang digunakan dalam penelitian ini adalahSMA/MA Negeri Mataram yang terdiri dari seluruh siswa kelasXI MIA MAN1 Mataram, XI IPA SMAN 2 Mataram, dan SMAN 6 Mataram yang berjumlah 592 siswa. Sampel yang digunakan sebanyak sebanyak 236 siswa. Teknik pengambilan sampel dalam penelitian ini adalah teknik purposive sampling (penentuan sampel dengan pertimbangan tertentu). Teknik dalam mengumpulkan data dengan mengunakan teknik observasi dan teknik angket, serta dokumentasi di mana terlebih dahulu dibuat instrumen yang telah diuji validitas dan reliabilitasnya [12].

\section{HASIL DAN PEMBAHASAN}

Keterampilan pengambilan keputusan siswa di MAN 1 Mataram, SMAN 2 Mataram, dan SMAN 6 Mataram, yaitu dengan persentase rata-rata secara berturut-turut sebesar $71,24 \%, 73,98 \%$, dan $70,17 \%$. Persentase rata-rata keterampilan pengambilan keputusan yang diperoleh di tiga sekolah tersebut ratarata menunjukkan masuk dalam kriteria yang baik dengan persentase rata-rata tertinggi diperoleh oleh SMAN 2 Mataram dengan menggunakan metode ceramah dan persentase rata-rata terendah diperoleh oleh SMAN 6 Mataram dengan menggunakan metode diskusi untuk lebih jelasnya dapat dilihat pada Gambar 1.

Gambar 1 menunjukan perbedaan persentase rata-rata keterampilan pengambilan keputusan yang diperoleh. Aspek mengevaluasi pilihan merupakan aspek dengan rata-rata persentase yang paling tinggi diantara aspek-aspek yang lainnya. Hal ini menunjukkan bahwa siswa di tiga sekolah mampu mengevaluasi pilihan yang dipilihnya dengan mengetahui kelebihan dan kekurangan dari informasi yang didapatkan menjadi suatu pilihan yang akan dipilih. Rincian data hasil setiap aspek-aspek 
keterampilan pengambilan keputusan pada setiap sekolahdisajikan dalam Tabel 1.

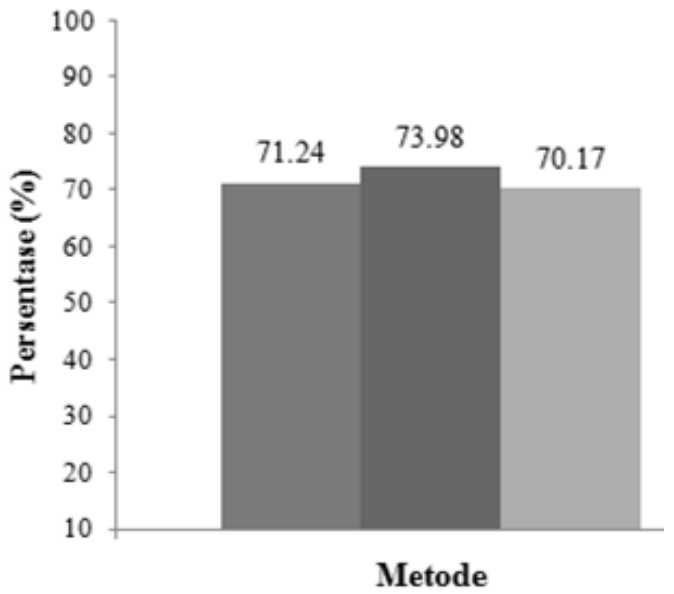

Gambar 1 Grafik Persentase Rata-Rata Keterampilan Pengambilan Keputusan Siswa. Biru $\mathrm{T}_{\mathrm{A} 1}$ : MAN 1 Mataram metode penugasan; Merah $\mathrm{C}_{\mathrm{A} 2}$ : SMAN 2 Mataram metode ceramah; Hijau $\mathrm{D}_{\mathrm{A} 3}$ : SMAN 6 Mataram metode diskusi

Aspek merumuskan masalah merupakan aspek dengan rata-rata persentase terendah dari aspekaspek yang lainnya. Aspek merumuskan masalah masuk dalam kategori yang baik. Hal ini menunjukan bahwa siswa di tiga sekolah mampu merumuskan masalah dan mengetahui masalah apa yang akan dipecahkan. Metode yang paling baik pada aspek ini adalah metode penugasan yang digunakan di MAN 1 Mataram dengan persentase $72,38 \%$ diikuti metode ceramah yang digunakan di SMAN 2 Mataram dengan persentase $71,37 \%$ dan metode diskusi yang digunakan di SMAN 6 Mataram dengan persentase $68,45 \%$ untuk lebih jelasnya dapat dilihat pada Gambar 2.

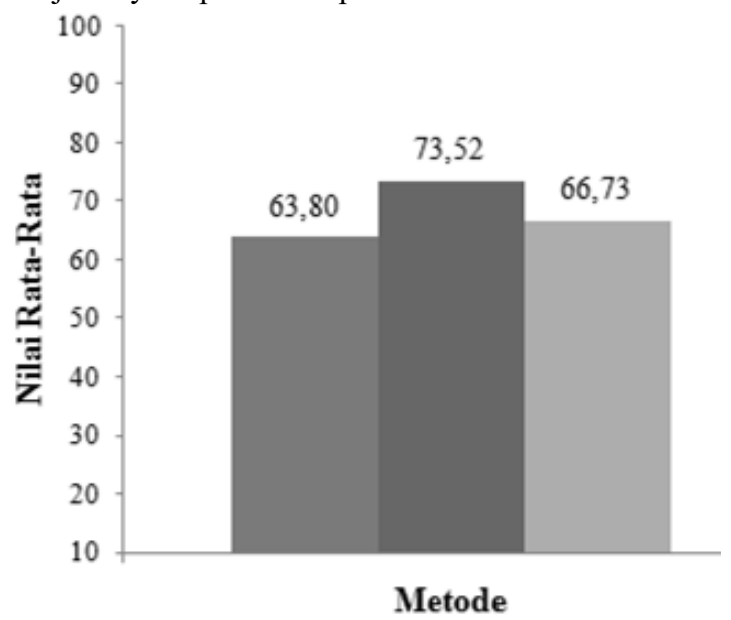

Gambar 2 Grafik Nilai Rata-RataHasil Belajar Siswa.Biru $\mathrm{T}_{\mathrm{A1}}$ : MAN 1 Mataram metode penugasan; Merah $\mathrm{C}_{\mathrm{A} 2}$ : $\mathrm{SMAN} 2$ Mataram metode ceramah; Hijau $\mathrm{D}_{\mathrm{A} 3}$ : SMAN 6 Mataram metode diskusi
Hasil belajar siswa dengan rata-rata nilai tertinggi diperoleh di SMAN 2 Mataram dengan menggunakan metode ceramah sebesar 73,52 diikuti oleh SMAN 6 Mataram dengan menggunakan metode penugasan sebesar 66,73 dan rata-rata nilai terendah diperoleh di MAN 1 Mataram dengan menggunakan metode penugasan untuk lebih jelasnya dapat dilihat pada Gambar 2.

Gambar 2 menunjukan perbedaan nilai ratarata hasil belajar yang diperoleh siswa di tiga sekolah. Metode pembelajaran yang digunakan di SMAN 2 Mataram adalah ceramah, di mana dengan metode ceramah lebih baik dari pada metode diskusi yang digunakan di SMAN 6 Mataram dan metode penugasan yang digunakan di MAN 1 Mataram. Hal ini dikarenakan siswa lebih terbiasa dalam pembelajaran guru meyampaikan pembelajaran dengan menggunakan metode ceramah.

Guru menyampaikan pembelajaran dengan metode ceramah lebih memberikan semua materi yang diperlukan siswa untuk belajar, sehingga siswa cenderung kurang memahami materi yang diajarkan. Hal ini terlihat dari rendahnya aspek keterampilan pengambilan keputusan siswa pada aspek merumuskan masalah apabila dibandingkan dengan menggunakan metode penugasan yang aspek merumuskan masalah lebih tinggi (Tabel 1). Penggunaan metode ceramah membuat siswa cenderung hanya mengandalkan informasi yang disampaikan guru saja. Pernyataan ini didukung oleh hasil observasi, di mana didapatkan hasil bahwa dalam mengumpulkan informasi yang relavan pada metode ceramah persentase di bawah $65 \%$, yaitu sebesar $60,94 \%$ masuk dalam kategori kurang yang berarti siswa di SMAN 2 Mataram kurang dalam mencari informasi. Hasil ini selaras dengan hasil penelitian sebelumnya $[13,14]$

Analisis uji hipotesis dalam penelitian ini menggunakan uji anakova yang digunakan untuk melihat hubungan antara metode pembelajaran dengan keterampilan pengambilan keputusan dan hasil belajar kimia siswa kelas XI. Uji anakova merupakan perpaduan dari analisis varians dan analisis regresi linear. Penggunaan uji anakova mensyaratkan data penelitian yang akan dianalisis terdistribusi normal dan homogen, berdasarkan data perhitungan homogenitas data dan normalitas data, data penelitian memenuhi syarat untuk dilakukan analisis dengan uji anakova. Hasil perhitungan statistik uji anakova didapatkan nilai $F_{\text {hitung }}$ sebesar 22,58 yang dibandingkan dengan $\mathrm{F}_{\text {tabel }}$ pada taraf signifikan 5\% dengan db 2:232 sebesar 3,03. Harga $F_{\text {hitung }}>F_{\text {tabel }}$, maka hipotesis nol $\left(\mathrm{H}_{0}\right)$ ditolak, yang artinya ada hubungan antara metode pembelajaran dengan keterampilan pengambilan keputusan dan hasil belajar kimia siswa kelas XI IPA di SMA/MA Negeri Mataram Tahun Ajaran 2017/2018. 
Tabel 1 Hasil Angket Keterampilan Pengambilan Keputusan Setiap Aspek.

\begin{tabular}{lcccc}
\hline \multirow{2}{*}{ Aspek Keterampilan Pengambilan Keputusan } & \multicolumn{3}{c}{ Persentase (\%) } & \multirow{2}{*}{ Rata-Rata } \\
\cline { 2 - 4 } & $\mathrm{T}_{\mathrm{A} 1}$ & $\mathrm{C}_{\mathrm{A} 2}$ & $\mathrm{D}_{\mathrm{A} 3}$ & \\
\hline Merumuskan Masalah & 72,38 & 71,37 & 68,45 & 70,73 \\
Mengumpulkan Informasi yang Relevan & 68,47 & 74,05 & 69,79 & 70,77 \\
Membangun Pilihan-Pilihan & 70,00 & 72,85 & 69,70 & 70,85 \\
Mengevaluasi Pilihan & 74,22 & 77,90 & 73,26 & 75,13 \\
Mengambil Keputusan & 71,11 & 73,74 & 69,65 & 71,50 \\
\hline \multicolumn{1}{c}{ Rata-Rata } & 71,24 & 73,98 & 70,17 & 71,80 \\
\hline \multicolumn{2}{c}{} & & &
\end{tabular}

Berdasarkan uji hipotesis tersebut menunjukkan bahwa ada hubungan antara metode pembelajaran dengan keterampilan pengambilan keputusan dan hasil belajar kimia siswa kelas XI IPA, adapun keterampilan pengambilan keputusan memiliki kontribusi dalam mempengaruhi hasil belajar kimia siswa. Keterampilan pengambilan keputusan pada penelitian ini berkorelasi dengan hasil belajar sebesar $2,25 \%$ dan sisanya $97,75 \%$ dipengaruhi oleh faktorfaktor lain yang tidak diteliti dalam penelitian ini. Rendahnya kontribusi keterampilan pengambilan keputusan terhadap hasil belajar kimia siswa menunjukkan bahwa keterampilan pengambilan keputusan ini dalam kesaharian pembelajaran belum dilatihkan oleh guru.

\section{KESIMPULAN}

Uji hipotesis penelitian menggunakan uji anakova satu jalur menunjukkan bahwa ada hubungan antara metode pembelajaran dengan keterampilan pengambilan keputusan dan hasil belajar kimia siswa kelas XI IPA di SMA/MA Negeri Mataram Tahun Ajaran $2017 / 2018$.

\section{DAFTAR PUSTAKA}

[1] Konur, Kader Birinci. 2016. Pre-service Science and Primary School Teachers Identification of Scientific Process Skills. Universal Journal of Educational Research, 4(6): 1273-1281.

[2] Wulan, A. R. (2008). Skenario Baru bagi Implementasi Asesmen Kinerja pada Pembelajaran Sains di Indonesia. Jurnal Pendidikan, 32(3), 1-10.

[3] Widyatiningtyas, R. (2006). Pembentukan Pengetahuan Sains, Teknologi, dan Masyarakat dalam Pandangan Pendidikan IPA. EDUCARE, 1(2).

[4] Suryanti. 2012. Profil Kemampuan Berpikir Pengambilan Keputusan Berdasarkan IPA Ssiwa $S D$. Surabaya: Unesa University Press.

[5] Anggareni, N. W., Ristiati, N. P., \& Widiyanti, N. L. P. M. (2013). Implementasi strategi pembelajaran inkuiri terhadap kemampuan berpikir kritis dan pemahaman konsep IPA siswa
SMP. Jurnal Pendidikan dan Pembelajaran IPA Indonesia, 3(1).

[6] Zakrah, Z., Lestari, N., \& Kusmiyati, K. (2015). Pengaruh strategi pembelajaran discovery terhadap kemampuan berpikir kritis siswa pada mata pelajaran IPA kelas VIII di SMPN 3 Gunungsari tahun ajaran 2014/2015. Jurnal pijar MIPA, 10(2).

[7] Sari, S., \& Wijayanti, A. (2017). Talking Stick: Hasil Belajar IPA Dan Kemampuan Kerjasama Siswa. WACANA AKADEMIKA: Majalah Ilmiah Kependidikan, 1(2).

[8] Sudarmo, Unggul. 2004. Kimia untuk SMA Kelas $X I$. Jakarta: Erlangga.

[9] Campbell, W. Keith. 2004. Narcissism, Confidence, and Risk Attitude. Journal of Behavioral Decision Making, 17: 297-311.

[10] Adair, John. 2007. Decision Making and Problem Solving Strategies. London: Kogan Page.

[11] Hamdi, Asep Saepul. 2014. Metode Penelitian Kuantitatif Aplikasi dalam Pendidikan. Yogyakarta: Deepublish.

[12] Sugiyono. 2014. Statistik untuk Penelitian. Bandung : Alfabeta.

[13] Pritami, S. E., Purwoko, A. A., \& Savalas, L. R. T. 2014. Hubungan Iklim Kelas Dan Sikap Siswa Terhadap Pelajaran Kimia Dengan Prestasi Belajar Kimia Siswa Kelas Xi IPA SMA Negeri Se-Kota Mataram Tahun Pelajaran 2012/2013. Jurnal Pijar Mipa, 9(2).

[14] Isnani, G. 2017. The Influence of Classroom Climate, Learning Interest, Learning Discipline and Learning Motivation to Learning Outcomes on Productive Subjects. Jurnal Pendidikan Bisnis dan Manajemen, 3(2), 85-96. 